\title{
Effect of salt on ROS homeostasis, lipid peroxidation and antioxidant mechanisms in Pinus pinaster suspension cells
}

\author{
Herlânder AZEVEdo*, Vítor AMORIM-SiLVA, Rui M. TAVARES \\ Departamento de Biologia, Universidade do Minho, Campus de Gualtar, 4710-057 Braga, Portugal
}

(Received 20 February 2008; accepted 19 November 2008)

\author{
Keywords: \\ $\mathrm{H}_{2} \mathrm{O}_{2}$ / \\ maritime pine / \\ $\mathrm{NaCl} /$ \\ superoxide
}

\begin{abstract}
- In the Pinus genus, information on the effectiveness of oxidative defence mechanisms during exposure to salt is lacking. The effect of salt stress imposition on ROS homeostasis was investigated using maritime pine (Pinus pinaster Ait.) suspension cells as a model system.

- Cells were maintained in MS-based medium, exposed to salt $(50,100$ and $150 \mathrm{mM} \mathrm{NaCl})$ and analysed for biomass production, evidencing a decreasing growth capacity. Use of $100 \mathrm{mM} \mathrm{NaCl}$ imposed severe salt stress without affecting cell viability, being chosen for subsequent studies on the ROS homeostasis of salt shock-treated suspension cells.

- Increased total ROS levels were evident on the second day of salt exposure, but a superoxide ion transient burst was immediately noticeable. Additionally, lipid peroxide formation seemed to correlate with superoxide ion breakdown. In-gel superoxide dismutase activity evidenced a FeSOD homodimer with strongly increasing activity between hours 12-48 of salt stress imposition. Subsequently, $P$. pinaster $\mathrm{Fe}$-Sod 1 and $c s A p x 1$ genes were isolated from a cDNA library and expression was shown to increase within 12-24 h.

- Results show that severe salt treatment generates oxidative stress in P. pinaster cells despite the induction of antioxidant systems, and suggest a putative involvement of ROS in salt stress signalling.
\end{abstract}

Mots-clés :

$\mathrm{H}_{2} \mathrm{O}_{2}$ /

pin maritime /

$\mathrm{NaCl} /$

superoxide
Résumé - Effet du stress salin sur l'homéostasie des formes réactives d'oxygène, la peroxydation des lipides et les mécanismes antioxydants dans des suspensions cellulaires de Pinus pinaster.

- Les informations sur les mécanismes de défense oxydative du pin en réponse à un stress salin sont rares. L'effet d'une exposition au sel sur l'homéostasie des formes réactives d'oxygène (FRO) a été étudié en utilisant une suspension cellulaire de pin maritime (Pinus pinaster Ait.) comme modèle. - Les cellules cultivées dans un milieu MS modifié ont été exposées au sel (50, 100 et $150 \mathrm{mM} \mathrm{NaCl})$ et l'analyse de la production de biomasse a révélé une réduction de leur croissance. Une concentration de $100 \mathrm{mM} \mathrm{NaCl}$, stress sévère qui n'affecte cependant pas la viabilité cellulaire, a été choisie pour les études suivantes.

- L'augmentation des teneurs en FRO est évidente le jour suivant l'enrichissement du milieu en sels mais une production transitoire d'ions superoxyde est immédiatement constatée. De plus, l'apparition de produits issus de la peroxydation des lipides semble concomitante à la disparition des ions superoxyde. La mesure par tests in-gel de l'activité de la superoxyde dismutase supporte l'implication d'un homodimère de FeSOD dont l'activité augmente fortement au bout de 12 et jusqu'à $48 \mathrm{~h}$ d'exposition au sel. Les gènes $F e$-Sod 1 et $c s A p x 1$, isolés d'une banque d'ADNc de $P$. pinaster, voient leur expression augmenter au bout de $12 \mathrm{~h}$ et jusqu'à $24 \mathrm{~h}$ de traitement.

- Les résultats montrent que de fortes concentrations de sels provoquent un stress oxydatif dans les cellules de $P$. pinaster malgré l'induction de réponses antioxydantes et suggèrent l'implication des ERO dans les voies de transduction du stress salin.

\footnotetext{
* Corresponding author: hazevedo@bio.uminho.pt
} 


\section{INTRODUCTION}

In plants, abiotic stress has been shown to disrupt the cellular homeostasis of cells and consequently generate oxidative stress (Mittler, 2002; Zhu, 2001). Particularly, salt stress severely affects plant productivity, being responsible for the generation of ion imbalances and hyperosmotic stress. As a consequence, secondary effects occur that include oxidative damage to cellular constituents (Zhu, 2001; Bor et al., 2003). Partially reduced and excited species of oxygen, usually designated reactive oxygen species (ROS), can react with many cellular substances leading to the oxidative destruction of cells (Mittler, 2002). In plants, the major ROS include hydrogen peroxide $\left(\mathrm{H}_{2} \mathrm{O}_{2}\right)$, superoxide ion $\left(\mathrm{O}_{2}^{-}\right)$, singlet oxygen $\left({ }^{1} \mathrm{O}_{2}\right)$ and hydroxyl radical $\left(\mathrm{HO}^{\bullet}\right)$ (Mittler et al., 2004). The maintenance of homeostatic levels of ROS in cells is achieved by the pools of antioxidants, namely of the ascorbateglutathione cycle, and by the activity of ROS scavenging enzymes, the most important being superoxide dismutase (SOD, EC 1.15.1.1), catalase (CAT, EC 1.11.1.6), ascorbate peroxidase (APX, EC 1.11.1.1) and glutathione peroxidase (GPX, EC 1.11.1.9) (Mittler et al., 2004). These enzymes have been found in most cellular organelles, demonstrating the importance of ROS scavenging to cellular viability. SODs, by dismutating $\mathrm{O}_{2}^{-}$into $\mathrm{H}_{2} \mathrm{O}_{2}$ and $\mathrm{O}_{2}$, constitute the only enzymatic mechanism of scavenging superoxide. Hydrogen peroxide can be scavenged by CAT and by peroxidases like APX and GPX, that reduce $\mathrm{H}_{2} \mathrm{O}_{2}$ via ascorbate and glutathione, respectively (reviewed by Mittler et al., 2004). The role of antioxidant enzymes in the tolerance to diverse environmental stresses, including salt stress, has been reported (Bor et al., 2003).

Maritime pine (Pinus pinaster Ait.) is one of the three main pine species in Europe, being native to the western Mediterranean basin. As a major reforestation species, P. pinaster has been grown extensively in setting dunes of coastal areas, where plants are highly exposed to salt spray. As a consequence of different salt tolerance between species, vegetation zonation can be observed in proportion to seashore distance. The high suitability, particularly amongst pines, of $P$. pinaster to the setting dune environment is a strong indicator of the presence of salt-adaptative mechanisms. We have addressed this issue at plant level, observing that tolerance to high $\mathrm{NaCl}$ concentrations is accompanied by changes in both the photosynthetic apparatus and the homeostasis of ROS (unpublished data). The association between salt and oxidative stresses has been previously confirmed: salt decreases water availability and disrupts the homeostasis of water potential and ion distribution, a process which is the basis for oxidative stress generation (Zhu, 2001). At plant level, over-reduction of the photosynthetic apparatus constitutes a major source of ROS (Osmond and Grace, 1995), but salt-associated oxidative stress can also be mediated by superoxide and hydrogen peroxide radicals at the levels of mitochondria and peroxisomes, respectively (Corpas et al., 1993; Hernandez et al., 1993). Furthermore, a novel role has been established for ROS as signalling intermediates during abiotic stress resistance (reviewed by Mittler et al., 2004), and the importance of non-photosynthetic
ROS generation during abiotic stress responses has been recently substantiated (reviewed by Van Breusegem et al., 2008).

The present study addresses the cell-level role of nonphotosynthetic ROS during the maritime pine salt stress response, by use of a heterotrophic suspension cell system. Salt stress impact on growth was measured and the homeostasis of various ROS subsequently analysed. Activation of ROSscavenging mechanisms was monitored at both protein and gene expression levels. For the purpose, a candidate gene approach was used to identify ROS-scavenging proteins putatively involved in the $P$. pinaster salt stress response.

\section{MATERIALS AND METHODS}

\section{1. $P$. pinaster suspension culture maintenance and characterization}

A heterotrophic Pinus pinaster suspension cell culture was previously established in our laboratory from root segments of maritime pine seedlings (Azevedo et al., 2008a). Suspension cells were maintained in Murashige and Skoog (MS) medium (Murashige and Skoog, 1962) supplemented with 3\% glucose, $5 \mathrm{mg} \mathrm{L}^{-1}$ dithiothreitol, $0.1 \mathrm{~g} \mathrm{~L}^{-1}$ myo-inositol, $1 \mathrm{mg} \mathrm{L}^{-1} \mathrm{BA}$ and $2 \mathrm{mg} \mathrm{L}^{-1}$ 2,4-D, at $\mathrm{pH}$ 6. Suspensions were maintained at $25^{\circ} \mathrm{C}$ and $100 \mathrm{rpm}$ in the dark. Subcultures were performed during the late exponential phase (every 12-14 days), by transferring $10 \mathrm{~mL}$ of the culture into $70 \mathrm{~mL}$ of fresh medium. For growth analysis under salt stress, flasks were supplemented with 50,100 or $150 \mathrm{mM} \mathrm{NaCl}$. Suspension cells from three independent cultures were gathered into a single inoculum that was used to inoculate five separate cultures to be characterized. Biomass was determined by removing aliquots containing $3 \mathrm{~mL}$ of suspended cells every 3 days under sterile conditions. Samples were filtered using pre-weighed GF/C filters (Whatman, Clifton, NJ, USA), and oven dried at $60{ }^{\circ} \mathrm{C}$ for 24 h. For salt stress experiments, $P$. pinaster suspended cells in mid-exponential growth phase were gathered from three independent cultures, centrifuged at $5000 \mathrm{~g}$ for $5 \mathrm{~min}$ and resuspended in MS medium, at a final density of $0.1 \mathrm{~g} \mathrm{FW} \mathrm{mL}^{-1}$. Medium was supplemented with $100 \mathrm{mM} \mathrm{NaCl}$ when required, and experiments were carried out using five independent replicas.

\subsection{Protein extraction}

Suspension cells were ground to a fine powder in liquid nitrogen. Approximately $1 \mathrm{~g}$ of fresh weight was thawed in 2-3 $\mathrm{mL}$ of protein extraction buffer $(50 \mathrm{mM}$ sodium phosphate at $\mathrm{pH} 7.0,1 \mathrm{mM}$ benzamidine, $0.1 \%$ 2-mercaptoethanol and $1 \%$ PVPP) and incubated on ice for $5 \mathrm{~min}$. After centrifugation at $15000 \mathrm{~g}$ for $15 \mathrm{~min}$ at $4{ }^{\circ} \mathrm{C}$, the supernatant was recovered and immediately used for enzyme assays or stored at $-80{ }^{\circ} \mathrm{C}$. Protein was quantified using the Coomassie Blue method (Sedmak and Grossberg, 1977). 


\subsection{ROS homeostasis analysis}

The superoxide radical $\left(\mathrm{O}_{2}^{-}\right)$was quantified by the reduction of XTT (Invitrogen-Molecular Probes, OR, USA) to a soluble formazan (Able et al., 1998). Immediately before salt stress imposition, $0.5 \mathrm{mM}$ XTT was added to the cell suspension, followed by incubation in the dark, at room temperature with agitation. Aliquots were removed periodically, and the reduced XTT form was quantified by measuring the absorbance of the supernatant at $470 \mathrm{~nm}$. The overall oxidative stress state of the cell was quantified using the cell-permeant 2',7'-dichlorodihydrofluorescein diacetate $\left(\mathrm{H}_{2} \mathrm{DCFDA}\right.$; Invitrogen-Molecular Probes, OR, USA) as previously described (Allan et al., 2001). $\mathrm{H}_{2}$ DCFDA is converted by non-specific cellular esterases to $\mathrm{H}_{2} \mathrm{DCF}$, which oxidizes in the presence of $\mathrm{H}_{2} \mathrm{O}_{2}$ and other reactive oxygen intermediates. The end product 2', $7^{\prime}$-dichlorofluorescein is highly fluorescent and able to diffuse out of the cell. This property was used to quantify the intracellular production of $2^{\prime}, 7^{\prime}$ dichlorofluorescein, by performing a spectrofluorimetric analysis of the supernatant. During the time course of salt stress imposition to pine suspension cells, $1 \mathrm{~mL}$ aliquots were removed and added $10 \mu \mathrm{L}$ of $20 \mu \mathrm{M} \mathrm{H} \mathrm{H}_{2}$ DCFDA. Cells were incubated in the dark, at room temperature, for 30 min with agitation. Samples were centrifuged at $8000 \mathrm{~g}$ for $5 \mathrm{~min}$ and the supernatant recovered. Relative fluorescence was quantified using a LS 50 Luminescence Spectrometer (Perkin Elmer) at an excitation wavelength of $488 \mathrm{~nm}$ and an emission wavelength of $525 \mathrm{~nm}$. Lipid peroxidation was quantified spectrophotometrically by the MDA-TBA method, which quantifies the end product of lipid peroxidation malondialdehyde (MDA) by reaction at low $\mathrm{pH}$ and high temperature with 2-thiobarbituric acid (TBA) (Loreto and Velikova, 2001). The reaction was initiated by adding $75 \mu \mathrm{L}$ of protein extract from salt stressed pine suspension cells, to $250 \mu \mathrm{L}$ of chilled reaction mixture, composed of $0.5 \%(\mathrm{w} / \mathrm{v})$ TBA in $20 \%$ (w/v) TCA. The mixture was incubated at $95{ }^{\circ} \mathrm{C}$ for $30 \mathrm{~min}$ and placed immediately on ice. Samples were centrifuged at $10000 \mathrm{~g}$ for $5 \mathrm{~min}$ at $4{ }^{\circ} \mathrm{C}$, and the supernatant recovered. Quantification of the MDA-TBA complex was performed by determining the absorbance of the supernatant at $532 \mathrm{~nm}$ and deducting non-specific absorbance at $600 \mathrm{~nm}$. The molar extinction coefficient of MDA-TBA complex, at $532 \mathrm{~nm}$, is $155 \mathrm{mM}^{-1} \mathrm{~cm}^{-1}$.

\subsection{Enzymatic assays}

SOD activity was determined after Native-PAGE electrophoresis on a $10 \%$ acrylamide gel (Beauchamp and Fridovich, 1971). Following the PAGE separation of $30 \mu \mathrm{g}$ of protein, the gel was incubated in $50 \mathrm{mM}$ Tris- $\mathrm{HCl}(\mathrm{pH} 8.0)$, $0.106 \mathrm{mM}$ riboflavin, $53.7 \mu \mathrm{M}$ EDTA, and $0.245 \mathrm{mM} \mathrm{NBT}$, for $30 \mathrm{~min}$, in the dark, with agitation. SOD isoforms were differentiated according to their sensitivity to $\mathrm{KCN}$ and $\mathrm{H}_{2} \mathrm{O}_{2}$ (Fe-SODs are resistant to $\mathrm{KCN}$ and inhibited by $\mathrm{H}_{2} \mathrm{O}_{2}$ ). Inhibition assays were carried out using gel replicas, pre-incubated for $30 \mathrm{~min}$ in $50 \mathrm{mM}$ Tris- $\mathrm{HCl}(\mathrm{pH} 8.0)$ containing $2 \mathrm{mM} \mathrm{KCN}$ or $5 \mathrm{mM} \mathrm{H}_{2} \mathrm{O}_{2}$, followed by incubation in SOD reaction solution for $30 \mathrm{~min}$, in the dark, with agitation. After incubation, the gels were transferred to a light box and exposed to white light. SOD activity was revealed as an achromatic band against a dark purple background.

\section{5. cDNA isolation and Northern blot analysis}

A $P$. pinaster cDNA library was constructed using the ZAP Express $^{T M}$ Synthesis Kit (Stratagene) and the ZAP Express ${ }^{T M}$ Gigapack ${ }^{\circledR}$ III Gold Cloning Kit (Stratagene) (Azevedo et al., 2003). Screening of the cDNA library was carried out according to the supplier's instructions. Heterologous cDNA probes $\mathrm{Fe}$-Sod1 (AF094831) and Apx1 (AF053474) from Zantedeschia aethiopica were used to isolate maritime pine Fe-Sod 1 (AY536055) and csApx1 (AY485994), respectively. Cell suspensions were ground to a fine powder in a mortar using liquid nitrogen. Total RNA extraction was performed using a CTAB-based method (Azevedo et al., 2003). Sample normalization and integrity assessment was carried out by formaldehyde gel electrophoresis with ethidium bromide staining. For Northern blot analysis, total RNA was isolated from pine suspension cells during the time course of salt stress imposition. RNA ( $20 \mu \mathrm{g})$ was resolved by $1.2 \%$ formaldehyde agarose gel electrophoresis and transferred to Hybond- $\mathrm{N}^{+}$nylon membranes (Amersham Biosciences). Membranes were hybridized with $100 \mathrm{ng}$ of ${ }^{32} \mathrm{P}$-labelled $\mathrm{Fe}$-Sod 1 and $\operatorname{csApx} 1$ cDNAs. Overnight hybridization was carried out at $42{ }^{\circ} \mathrm{C}$ in $50 \%$ formamide, $5 \mathrm{mM}$ EDTA (pH 8.0), $50 \mathrm{mM}$ sodium phosphate, $0.9 \mathrm{M} \mathrm{NaCl}, 10 \times$ Denhardts reagent, $0.1 \%$ SDS and $250 \mu \mathrm{g} / \mathrm{mL}$ denatured salmon sperm DNA, followed by successively stringent washes, until a final wash using $1 \times \mathrm{SSC}$ and $0.1 \% \mathrm{SDS}$, at $65{ }^{\circ} \mathrm{C}$, for $30 \mathrm{~min}$. Membranes were then exposed to BioMax MS film (Kodak) for three days.

\subsection{Phylogenetic analysis}

Unrooted phylogenetic trees were constructed using the PHYLIP software suit (http://evolution.genetics.washington. edu/phylip.html) and maximum likelihood as the method of inference. The phylogenetic analysis of $\mathrm{Fe}$-Sod 1 was performed considering $\mathrm{Fe}$-Sod sequences from other plant species, bacteria and Entamoeba histolytica as outroot. Phylogenetic analysis of Apx 1 was performed considering Apx from other higher plants and yeast cytochrome c peroxidase (CCP) as outroot.

\section{RESULTS}

\subsection{P. pinaster suspension cell growth under salt stress}

A previously established Pinus pinaster suspension cell culture was analysed for its growth response to different concentrations of $\mathrm{NaCl}$ (Fig. 1). In the absence of $\mathrm{NaCl}$, a 15 day 


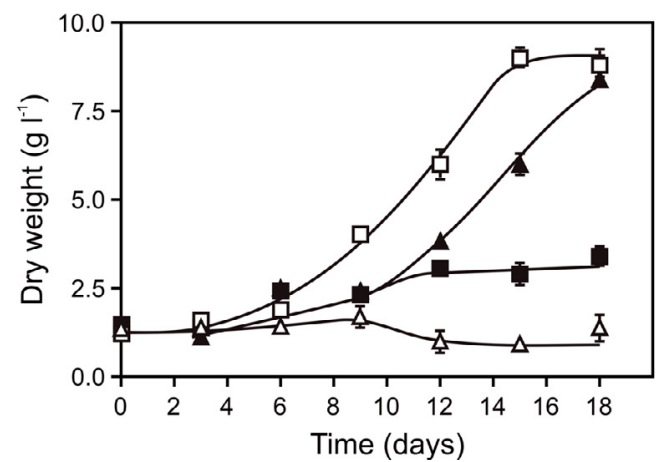

Figure 1. Dry weight estimation in $P$. pinaster suspension cultures grown for 18 days in MS medium supplemented at day 0 with $0 \mathrm{mM}$ (open square), $50 \mathrm{mM}$ (closed triangle), $100 \mathrm{mM}$ (closed square) and $150 \mathrm{mM}$ (open triangle) $\mathrm{NaCl}$. Bars represent standard errors of the means of five independent cultures, unless too small to visualize.

exponential growth phase was observed, immediately followed by a stationary phase. Increasing $\mathrm{NaCl}$ resulted in a concentration-dependant reduction of growth: $50 \mathrm{mM}$ delayed maximum biomass levels by three days; $100 \mathrm{mM}$ imposed a severe decline in biomass production; $150 \mathrm{mM}$ resulted in growth arrest and ultimately in biomass loss, suggesting a loss in cell viability. In light of these results, subsequent experiments were carried out using $100 \mathrm{mM} \mathrm{NaCl}$, as it imposed severe salt stress without affecting cell viability.

\subsection{Analysis of ROS homeostasis}

To analyse the homeostasis of ROS during salt stress, $P$. pinaster suspension cells in mid-exponential growth (day 8) were transferred to fresh medium containing $100 \mathrm{mM} \mathrm{NaCl}$, and analysed for the production of ROS and lipid peroxides. Results from the quantification of intracellular ROS levels (Fig. 2a) show that in the initial $24 \mathrm{~h}$, ROS were maintained at a basal level, increasing in the subsequent $24 \mathrm{~h}$ period. The tetrazolium dye XTT was used to measure the intracellular production of superoxide radical $\left(\mathrm{O}_{2}^{-}\right)$in the presence of $100 \mathrm{mM} \mathrm{NaCl}$. A burst of $\mathrm{O}_{2}^{-}$production was observed immediately after stress imposition, reaching a maximum peak within $12 \mathrm{~h}$ (Fig. 2b). Results suggest that $\mathrm{NaCl}$ immediately generates superoxide production, but the diminishing of superoxide levels within $12 \mathrm{~h}$ of incubation suggests the activation of anti-oxidant systems, namely the induction of superoxide dismutase. Lipid peroxidation is generally considered a marker for extensive oxidative stress and occurs as a consequence of ROS production (Petersen et al., 1999). Results from the quantification of lipid peroxide levels in salt-stressed suspension cells are depicted (Fig. 2c). According to this figure, no lipid peroxidation was observed in the initial $6 \mathrm{~h}$, after which levels suffered a steady increase.

Suspension cells subjected to sugar starvation (day 13) and therefore evidencing increased endogenous ROS levels, were resuspended in sugar-containing medium, resulting in a recovery to basal ROS levels (Fig. 2d). In the presence of $100 \mathrm{mM}$ a

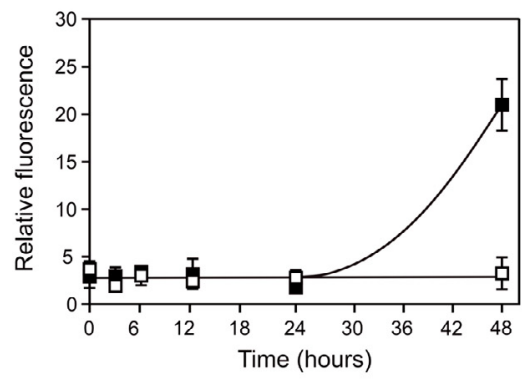

b

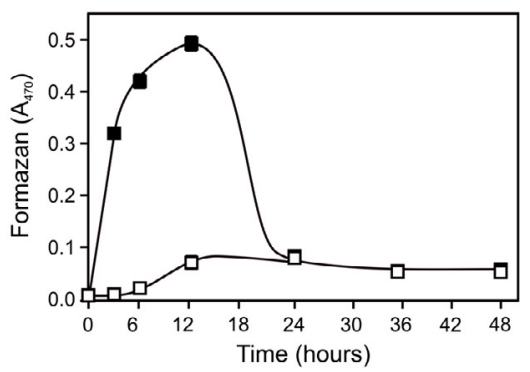

C

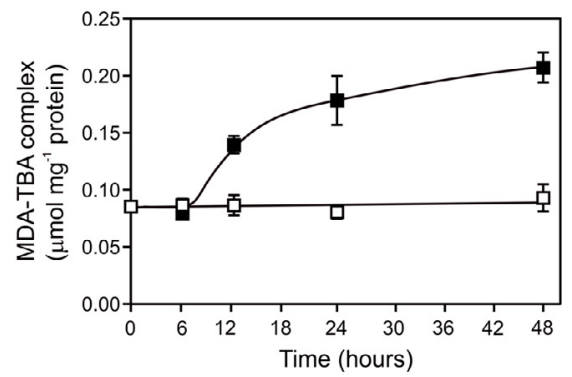

d

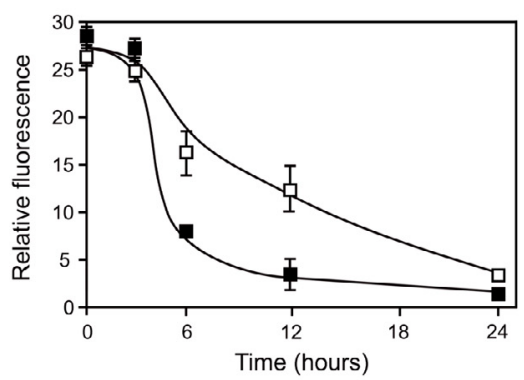

Figure 2. Analysis of various oxidative stress parameters in $P$. pinaster suspension cells subjected to salt stress imposition. Eightday old cultures supplemented with $0 \mathrm{mM}$ (open square) and $100 \mathrm{mM}$ (closed square) $\mathrm{NaCl}$ were analysed during a $48 \mathrm{~h}$ time course, for (a) the fluorescence produced by $\mathrm{H}_{2}$ DCFDA as a consequence of intracellular ROS, (b) the absorbance at $470 \mathrm{~nm}$ induced by the reaction of XTT with the superoxide radical, (c) the production of MDA-TBA complexes as a consequence of lipid peroxide presence. Thirteen-day old cultures supplemented with $0 \mathrm{mM}$ (open square) and $100 \mathrm{mM}$ (closed square) $\mathrm{NaCl}$ were analysed during a $24 \mathrm{~h}$ time course, for (d) the fluorescence produced by $\mathrm{H}_{2}$ DCFDA as a consequence of intracellular ROS. Bars represent standard errors of the means of five independent cultures, unless too small to visualize. 


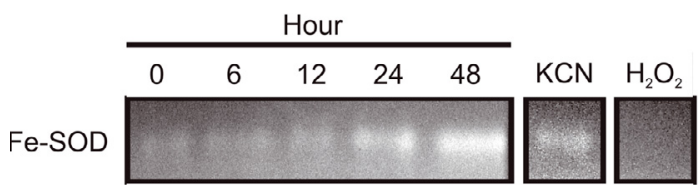

Figure 3. In-gel activity assay for superoxide dismutase (SOD) after Native PAGE electrophoretic separation of protein extracts, from $100 \mathrm{mM} \mathrm{NaCl}$-challenged $P$. pinaster suspension cells. Superoxide dismutase activity is depicted as achromatic bands in a dark background. Depiction of gel replicas $(t=0)$ incubated with $\mathrm{KCN}$ and $\mathrm{H}_{2} \mathrm{O}_{2}$ prior to SOD activity assay.

$\mathrm{NaCl}$, sugar-starved cells showed an increase in the recovery rate. These results are strongly supportive of an induction of anti-oxidant systems following challenging with $\mathrm{NaCl}$, suggesting that basal ROS levels observed in the early stages of salt stress imposition may result from increased ROSscavenging capacity rather than the absence of oxidative stress.

\subsection{Evaluation of the superoxide dismutase activity}

ROS homeostasis is balanced between the rates of ROS generation, reaction with cellular components and substances, and degradation by enzymatic/non-enzymatic antioxidants (reviewed by Mittler et al., 2004). In light of the previous results, superoxide dismutase activity was evaluated in protein extracts of pine suspended cells, during the time course of salt stress imposition. $P$. pinaster suspension cells have evidenced the presence of six isoforms of SOD: four MnSOD, one FeSOD and one $\mathrm{Cu}, \mathrm{ZnSOD}$ (data not shown). The in-gel activity assay revealed that one homodimer isoform, identified by $\mathrm{KCN} / \mathrm{H}_{2} \mathrm{O}_{2}$ specific inhibition to be a FeSOD, was the only isoform suffering changes in protein levels, with activity steadily increasing after $12 \mathrm{~h}$ of stress imposition (Fig. 3).

\subsection{Phylogenetic analysis of $P$. pinaster $\mathrm{Fe}-\mathrm{SOD}$ and $\operatorname{cs} A P X$}

The antioxidant capacity of $P$. pinaster cells during salt stress was analysed at the transcript level using a candidate gene approach to isolate genes involved in ROS-scavenging metabolism. Full-coding cDNA sequences were obtained by screening a maritime pine cDNA library (Azevedo et al., 2003), resulting in the identification of the genes $\mathrm{Fe}$-Sod 1 (acc. No. AY536055) and Apx1 (acc. no. AY485994).

The Fe-Sod 1 cDNA (929 bp) contained a putative $750 \mathrm{bp}$ open reading frame. The predicted protein of 249 a.a. residues has a molecular mass of $28.6 \mathrm{kDa}$ and a 7.63 isoelectric point. Comparison with full-sequence $\mathrm{Fe}-\mathrm{Sod}$ genes indicated the presence of a putative $\mathrm{N}$-terminal signalling peptide (data not shown). However, FeSOD1 protein targeting prediction using TargetP and PSORT softwares was inconclusive between a chloroplastic or peroxisomal targeting: despite the $\mathrm{N}$-terminus transit peptide, the a.a. sequence also presented a C-terminus peroxisomal matrix targeting sequence, PST1
[(S/A/C)(K/R/H)L], (Volokita, 1991). P. pinaster Fe-Sod 1 was the first described nucleotide sequence encoding a chloroplastic Fe-SOD in gymnosperms. Unrooted phylogenetic tree analysis clearly showed that plant Fe-SOD proteins cluster in a distinct subclade (Fig. 4). Results also suggest the existence of paralogue differentiation within Fe-SODs, which is in accordance with previous observations (Lino-Neto, 2001).

The Apxl cDNA (1084 bp) contained a putative $750 \mathrm{bp}$ open reading frame. The deduced a.a. sequence of 249 residues presented a predicted $27.3 \mathrm{kDa}$ mass and a 5.44 isoelectric point. $A P X 1$ sequence analysis indicated the absence of protein signalling peptides or of membranespanning regions, suggesting a cytosolic localization. Unrooted phylogenetic tree analysis suggests that $P$. pinaster Apx 1 codes for a cytosol-soluble (csAPX) isoform (Fig. 5). This is corroborated by the identity percentages observed between P. pinaster APX1 and csApx (73.3-76.9\%) in contrast to cmApx (58.7-58.8\%). P. pinaster Apx1 was the first databaseavailable nucleotide sequence encoding a cytosolic $A P X$ in gymnosperms.

\subsection{Expression analysis of $P$. pinaster $\mathrm{Fe}$-Sod 1 and $\operatorname{csApx} 1$}

Transcript levels of $F e$-Sod 1 and csApx 1 were analysed to ascertain the involvement of these enzymes in $P$. pinaster resistance to salt stress, as suggested by previous results. Results depicted in Figure 6 show that transcript levels of both genes increased slightly $12 \mathrm{~h}$ after salt-challenging, and increased substantially within $24 \mathrm{~h}$ of stress imposition, suggesting an activation of antioxidant enzymatic mechanisms during severe salt stress in maritime pine cell suspensions.

\section{DISCUSSION}

Pinus pinaster heterotrophic suspension cells have been successfully used to study plant-pathogen interactions and changes in nutrient uptake profiles (Azevedo et al., 2008a; $2008 b$ ). In the present study, this model was used to analyse the homeostasis of ROS during salt stress under nonphotosynthetic conditions. With regards to cell culture growth, it was observed that under normal conditions, $P$. pinaster suspension cells evidenced exponential growth and an absent lag phase, a behaviour already observed in other suspension cell models (Shimon-Kerner et al., 2000). Increasing concentrations of salt resulted in growth inhibition and eventual arrest, as expected from previous reports (Elkahouia et al., 2005). A concentration of $100 \mathrm{mM} \mathrm{NaCl}$ was subsequently chosen to impose severe salt stress without preventing cell growth.

Maritime pine suspension cells were able to maintain a low overall oxidative state in the initial $24 \mathrm{~h}$ of exposure to salt, but results also evidenced a transient $\mathrm{O}_{2}^{-}$burst. The correlation shown to exist between salt challenging and the production of superoxide radical $\left(\mathrm{O}_{2}^{-}\right)$in mitochondria (Corpas et al., 1993), might suggest that the observed $\mathrm{O}_{2}^{-}$burst may result from an 


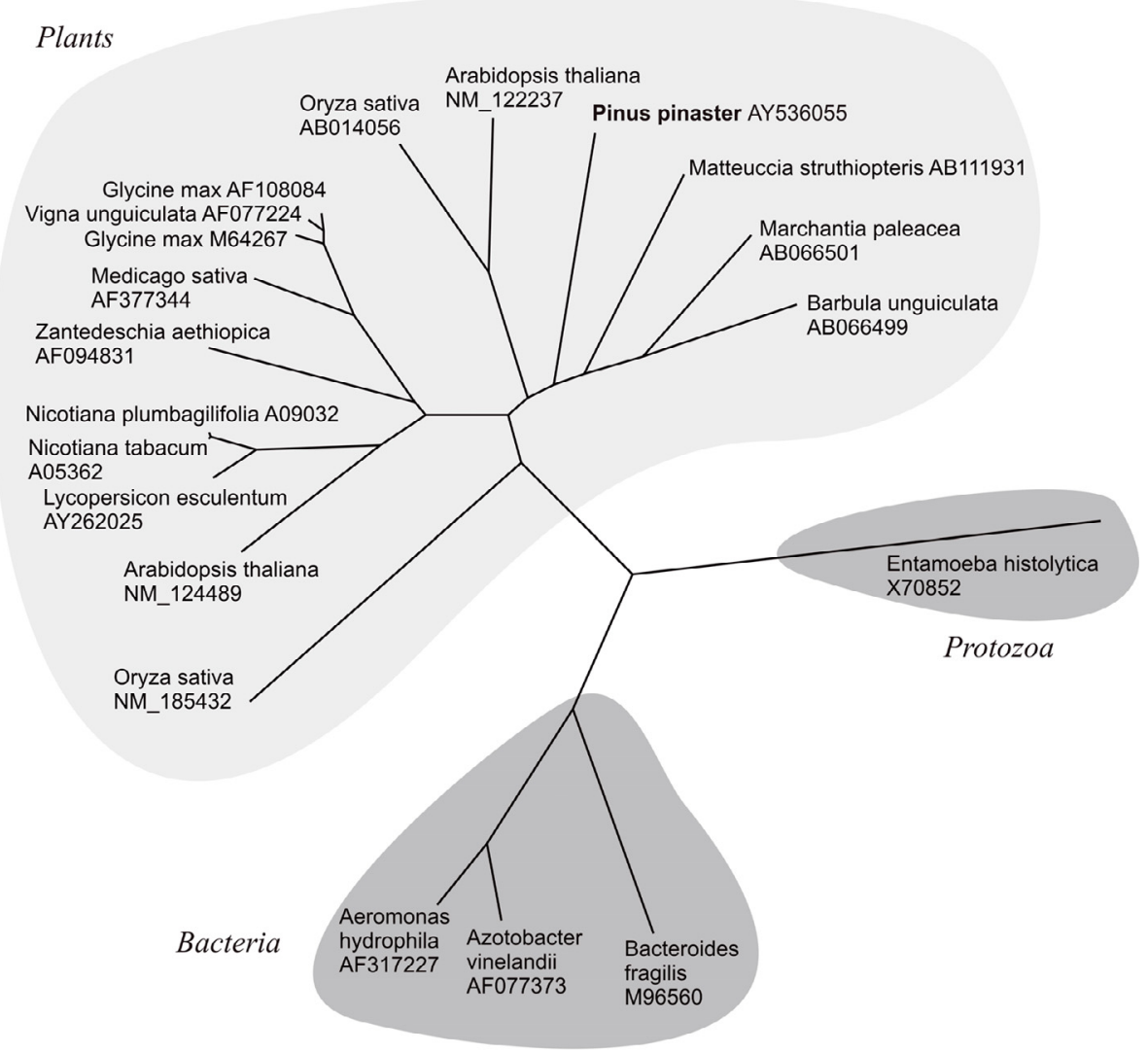

Figure 4. Unrooted tree representing the phylogenetic relationship between $P$. pinaster Fe-SOD and Fe-SOD's from other plants, Bacteria and Protozoa. The corresponding coding nucleotide sequences were analyzed using ClustalW and maximum-likelihood algorithms. The $P$. pinaster $\mathrm{Fe}-\mathrm{SOD}$ sequence is depicted in bold. GenBank accession numbers are indicated for all sequences.

affection of the respiratory electron chain. Meanwhile, studies have shown that not only biotic but also abiotic stress can be accompanied by an oxidative burst, which is mediated by the $\mathrm{O}_{2}^{-}$-generating enzyme NADPH oxidase, and is correlated with stress signalling (reviewed by Mittler et al., 2004).

Lipid peroxidation can be initiated by the hydroxyl radical $\left(\mathrm{HO}^{\circ}\right)$ and requires active $\mathrm{O}_{2}$ uptake (Fridovich, 1985). Since the reduction of transition metal by $\mathrm{O}_{2}^{-}$is required for the generation of $\mathrm{HO}^{\bullet}$ (together with $\mathrm{H}_{2} \mathrm{O}_{2}$ presence), the dismutation of $\mathrm{O}_{2}^{-}$by SODs should suppress the generation of $\mathrm{HO}^{\bullet}$. However, results seem to indicate that steady levels of $\mathrm{HO}^{\bullet} /$ lipid peroxides are being generated in maritime pine suspension cells as a consequence of salt stress imposition. In the cell, lipid peroxidation leads to membrane permeability and loss of integrity, and ultimately to solute leakage and cellular damage (Bor et al., 2003). During salt stress, low levels of lipid peroxides have been related to the increased antioxidant capacity of salt tolerant/resistant species or cultivars (Radic et al., 2006; Ruiz et al., 2005), whereas high lipid peroxide levels were associated with salt-sensitivity (Bor et al., 2003; Koca et al., 2007; Masood et al., 2006).

As previously stated, it has been hypothesised that most forms of stress, by generating ROS, led to the development of novel roles for ROS as versatile signalling molecules. They act not only in abiotic but also in biotic stress sensing, with a predominant role being led by superoxide ion (reviewed by Mittler et al., 2004). Even though a transient burst of $\mathrm{O}_{2}^{-}$ was observed in maritime pine cells, the specific thresholds for each ROS that determine their roles as signal modulators or toxic molecules are still unknown. The subsequent accumulation of total ROS and lipid peroxides, which are tightly linked with the incapacity to scavenge excess ROS, suggest that $100 \mathrm{mM} \mathrm{NaCl}$ causes severe oxidative stress in P. pinaster suspension cells.

When suspension cells subjected to sugar starvation and therefore evidencing increased endogenous ROS levels were transferred to sugar-containing medium, they were able to recover to basal ROS levels, showing an increase in the recovery rate in the presence of salt. These results are strongly supportive of an induction of anti-oxidant systems following challenging with $\mathrm{NaCl}$, suggesting that basal ROS levels observed in the early stages of salt stress imposition may result from increased ROS-scavenging capacity rather than the absence of oxidative stress. The involvement of soluble sugars (e.g. sucrose, glucose, fructose) in the dynamics of ROS and the response of plants to oxidative stress has been reported (revised by Couée et al., 2006). Soluble sugars seem to assume a dual role with respect to ROS, being involved in both ROS-producing pathways and the feeding of NADPHproducing pathways, which contribute to ROS scavenging. In 


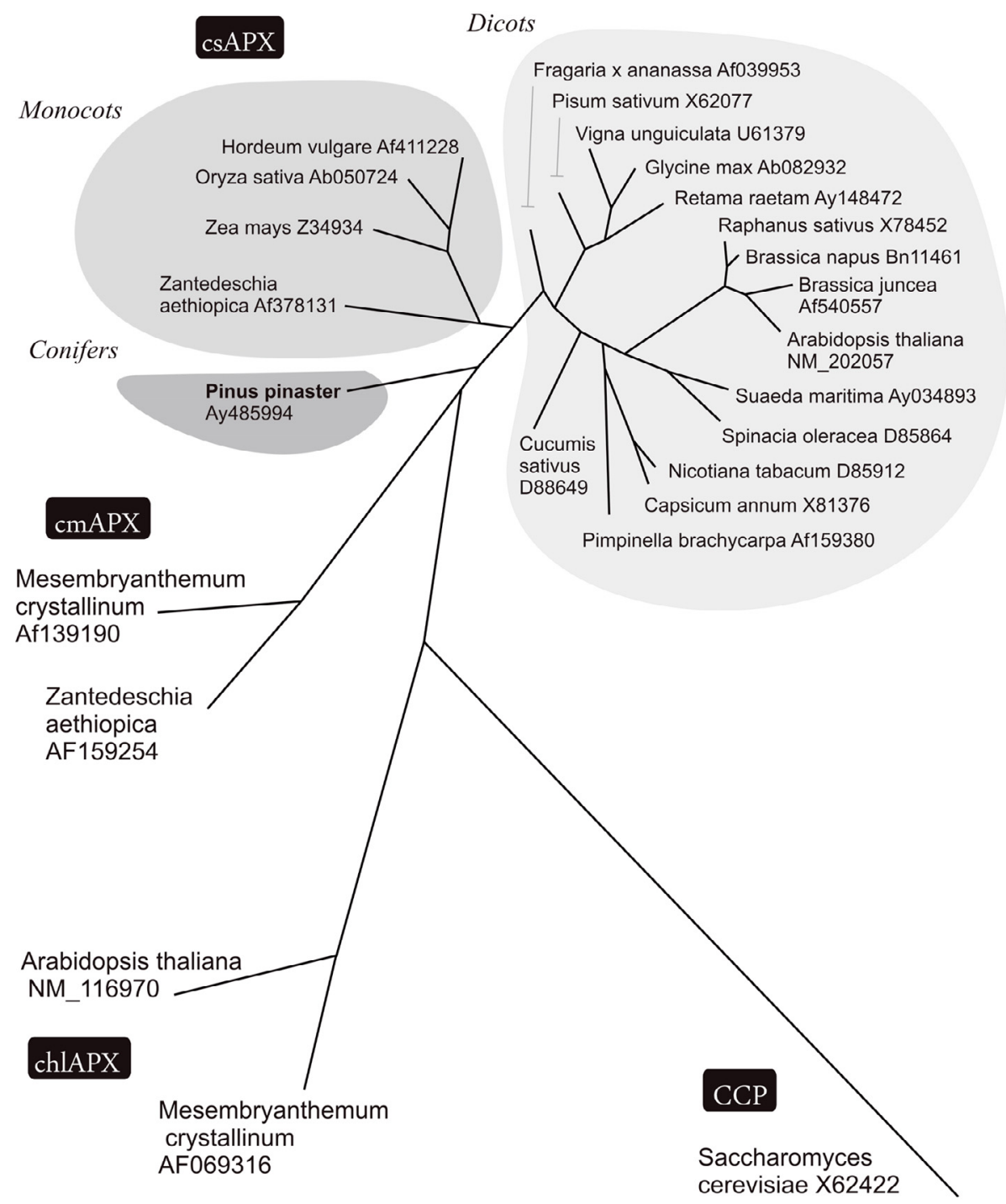

Figure 5. Unrooted tree representing the phylogenetic relationship between P. pinaster csAPX and APX's from other higher plants. Isoforms are indicated as chloroplastic (chl), cytosolic soluble (cs) and cytosolic membrane-bound (cm) APX, as well as the outroot cytochrome $c$ oxidase (CCP) from the yeast $S$. cereviseae. The P. pinaster APX sequence is depicted in bold. GenBank accession numbers are indicated for all sequences.

plants, sugar starvation can induce an increase of ROS levels, as a consequence of alterations in the respiratory pathway, due to a decrease of ADP regeneration and consequently the appearance of "state 4" respiration, or due to the occurrence of lipid mobilization, fatty acid transfer, and peroxisomal $\beta$ oxidation. The role of sugar feeding in the increase of antioxidative protection associated to stress responses is mediated through sugar-specific signalling pathways, although differences can be observed regarding the nature of the sugar and the stress. According to Coué et al. (2006), the relationship between soluble sugars and ROS production or between soluble sugars and ROS responses is not a straightforward positive correlation, since high sugar levels can correspond to the activation of some ROS-producing pathways and decrease other ROS-producing pathways, and both high and low sugar level can result in the enhancement of ROS responses. None withstanding, the present results support the presence of separate mechanisms/signalling pathways mediating the decrease of endogenous ROS levels following sugar and salt stress perception.

Results suggest that maritime pine suspension cells respond to salt stress by enhancing their antioxidative capacity. ROSscavenging mechanisms do not seem to deter the adverse effect of salt, but should reduce oxidative stress to levels that allow cell growth, enabling suspension cells to withstand $100 \mathrm{mM}$ $\mathrm{NaCl}$ concentrations in the extracellular medium. In this context, it should be useful to observe responses under lower salinity exposure (e.g. $50 \mathrm{mM} \mathrm{NaCl}$ ). In $P$. pinaster the increased antioxidant capacity seemed to involve the activation of FeSOD and csAPX, with FeSOD having a preponderant role when compared with remaining SOD isoforms. These results corroborate previous protein and gene expression data. 


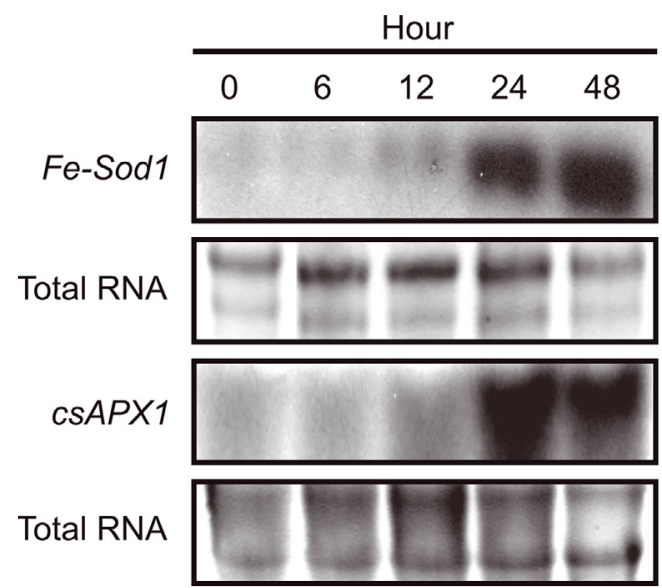

Figure 6. Time course expression analysis of $P$. pinaster $\mathrm{Fe}-\mathrm{Sod} 1$ and $c s A P X 1$ during $100 \mathrm{mM} \mathrm{NaCl}$ challenging of maritime pine suspension cells. Total RNA samples were separated on a denaturing formaldehyde gel, blotted and hybridized with homologous cDNA ${ }^{32}$ P-labeled probes. Total RNA was used as loading control.

SOD activity was long predicted to help in the scavenging of excessive amounts of superoxide ions generated, for instance, in mitochondria (Boveris and Chance, 1973). An induction in the activity of SOD following salt stress has been frequently observed, either with total activity (Koca et al., 2007; Masood et al., 2006) or isoform analysis (Elkahouia et al., 2005). Previous evidence has shown that, in tobacco suspension cells, FeSOD is the main isoform involved in the control of cellular $\mathrm{O}_{2}^{-}$levels (Kurepa et al., 1997).

SOD enzymatic activity is suggested to protect cells by scavenging $\mathrm{O}_{2}^{-}$, and also by decreasing the risk of $\mathrm{HO}^{\bullet}$ generation by the transition metal-catalyzed Haber-Weiss reaction. On the other hand, ascorbate is the most important reducing substrate for $\mathrm{H}_{2} \mathrm{O}_{2}$ detoxification (Noctor and Foyer, 1998). Ascorbate peroxidase (APX) is a multigenic family with various isoforms (Asada, 1994), in which cytosolic APX plays a fundamental role in non-photosynthetic tissues, by preventing $\mathrm{H}_{2} \mathrm{O}_{2}$ dependent inhibition of cytosolic enzymes (Verniquet et al., 1991). Overexpression of various isoforms of SOD has been shown to confer improved tolerance to oxidative stress (Bowler et al., 1991; Perl et al., 1993). Moreover, overexpression of SOD and APX isozymes has been previously co-related with salt tolerance (Kaminaka et al., 1999; Wang et al., 1999), and the involvement of APX in the mechanisms of salt tolerance has also been substantiated at protein level (Elkahouia et al., 2005; Koca et al., 2007; Masood et al., 2006). Finally, present results are corroborated by microarray transcript profiling of salt-challenged Arabidopsis plants, in which all three $\mathrm{Fe}-\mathrm{SOD}$, but none other SOD isoform, presented induced expression. A similar induction was observed for the cytosolic APX1 (reviewed by Mittler et al., 2004).

With the onset of worldwide soil salinization, a better understanding of plant-salinity relations is determinant not only for cultivars but also for forest species. Present data confirms the activation of ROS-scavenging mechanisms as part of the $P$. pinaster cellular response to salt stress, and suggests a possible role of transient superoxide production in stress signalling. The use of in vitro heterotrophic suspension cultures may allow further insight onto the cellular/molecular aspects of resistance, particularly with regards to the role of ROS of non-photosynthetic origin. Nonetheless, and in order to clarify the extent of maritime pine tolerance/resistance to salt, further studies are being carried out at plant level, correlating salt stress with ROS homeostasis and the effect of salt imposition on the photosynthetic apparatus.

Acknowledgements: H. Azevedo is supported by FCT, grant reference SFRH/BPD/17198/2004. V. Amorim-Silva is supported by FCT, grant reference SFRH/BD/38583/2007.

\section{REFERENCES}

Able A.J., Guest D.I., and Sutherland M.W., 1998. Use of a new tetrazolium-based assay to study the production of superoxide radicals by tobacco cell cultures challenged with avirulent zoospores of Phytophthora parasitica var nicotianae. Plant. Physiol. 117: 491499.

Allan A.C., Lapidot M., Culver J.N., and Fluhr R., 2001. An early tobacco mosaic virus-induced oxidative burst in tobacco indicates extracellular perception of the virus coat protein. Plant Physiol. 126: 97-108.

Asada K., 1994. Production and action of active oxygen species in photosynthetic tissues. In: Foyer C.H. and Mullineaux P.M. (Eds.), Production and action of active oxygen species in photosynthetic tissues, CRC Press, Boca Raton, pp. 77-104.

Azevedo H., Lino-Neto T., and Tavares R.M., 2003. An improved method for high-quality RNA isolation from needles of adult maritime pine trees. Plant Mol. Biol. Rep. 21: 333-338.

Azevedo H., Dias A.C.P., and Tavares R.M., 2008a. Establishment and characterization of Pinus pinaster suspension cell cultures. Plant Cell Tiss. Organ Cult. 93: 115-121.

Azevedo H., Lino-Neto T., and Tavares R.M. 2008b. The necrotroph Botrytis cinerea induces a non-host Type II resistance mechanism in Pinus pinaster suspension-cultured cells. Plant Cell Physiol. 49: 386-395.

Beauchamp C. and Fridovich I., 1971. Superoxide dismutase: improved assay and an assay applicable to acrylamide gels. Anal. Biochem. 44: 276-286.

Bor M., Ozdemir F., and Turkan I., 2003. The effect of salt stress on lipid peroxidation and antioxidants in leaves of sugar beet Beta vulgaris L. and wild beet Beta maritima L. Plant Sci. 164: 77-84.

Boveris A. and Chance B., 1973. The mitochondrial generation of hydrogen peroxide. Biochem. J. 134: 707-716.

Bowler C., Slooten L., Vandenbraden S., Rycke R.D., Botterman J., Sybesma C., Montagu M.V., and Inze D., 1991. Manganese superoxide dismutase can reduce cellular damage mediated by oxygen radicals in transgenic plants. EMBO J. 10: 1723-1732.

Corpas F.J., Gomez M., Hernandez J.A., and Del Rio L.A., 1993. Metabolism of activated oxygen in peroxisomes from two Pisum sativum L. cultivars with different sensitivity to sodium chloride. J. Plant Physiol. 141: 160-165.

Couée I., Sulmon C., Gouesbet G., and El Amrani A., 2006. Involvement of soluble sugars in reactive oxygen species balance and responses to oxidative stress in plants. J. Exp. Bot. 57: 449-459.

Elkahouia S., Hernández J.A., Abdellyc C., Ghrira R., and Limama F., 2005. Effects of salt on lipid peroxidation and antioxidant enzyme activities of Catharanthus roseus suspension cells. Plant Sci. 168: 607-613. 
Fridovich I., 1985. Biological effects of the superoxide radical. Arch. Biochem. Biophys. 247: 1-11.

Hernandez J.A., Corpas F.J., Gomez M., del Rio L.A., and Sevilla F., 1993. Salt-induced oxidative stress mediated by activated oxygen species in pea leaf mitochondria. Physiol. Plant. 89: 103-110.

Kaminaka H., Morita S., Tokumoto M., Masumura T., and Tanaka K., 1999. Differential gene expressions of rice superoxide dismutase isoforms to oxidative and environmental stresses. Free Rad. Res. 31: 219-225.

Koca H., Bor M., Ozdemir F., and Turkan I., 2007. The effect of salt stress on lipid peroxidation, antioxidative enzymes and proline content of sesame cultivars. Environ. Exp. Bot. 60: 344-351.

Kurepa J., Hérouart D., Van Montagu M., and Inzé D., 1997. Differential expression of $\mathrm{CuZn}$ - and $\mathrm{Fe}$-superoxide dismutase genes of tobacco during development, oxidative stress, and hormonal treatments. Plant Cell Physiol. 38: 463-470.

Lino-Neto T., 2001. Role of oxidative stress enzymes during Zantedeschia aethiopica spathe whitening and regreening, Minho University, Braga, $284 \mathrm{p}$.

Loreto F. and Velikova V., 2001. Isoprene produced by leaves protects the photosynthetic apparatus against ozone damage, quenches ozone products and reduces lipid peroxidation of cellular membranes. Plant Physiol. 127: 1781-1787.

Masood A., Shah N.A., Zeeshan M., and Abraham G., 2006. Differential response of antioxidant enzymes to salinity stress in two varieties of Azolla (Azolla pinnata and Azolla filiculoides). Environ. Exp. Bot. 58: $216-222$.

Mittler R., 2002. Oxidative stress, antioxidants and stress tolerance. Trends Plant Sci. 7: 405-410.

Mittler R., Vanderauwera S., Gollery M., and Van Breusegem F., 2004. Reactive oxygen gene network of plants. Trends Plant Sci. 9: 490498.

Murashige T. and Skoog F., 1962. A revised medium for rapid growth and bio assays with tobacco tissue cultures. Physiol. Plant. 15: 473-497.

Noctor G. and Foyer C.H., 1998. Ascorbate and glutathione: keeping active oxygen under control. Annu. Rev. Plant Physiol. Plant Mol. Biol. 49: $249-279$.
Osmond C.B. and Grace S.C., 1995. Perspectives on photoinhibition and photorespiration in the field: quintessential inefficiencies of the light and dark reactions of photosynthesis. J. Exp. Bot. 46: 1351-1362.

Perl A., Perl-treves R., Galili G., Aviv D., Shalgi E., Malkin S., and Galun E., 1993. Enhanced oxidative-stress defence in transgenic potato plants expressing tomato $\mathrm{Cu}, \mathrm{Zn}$ superoxide dismutase. Theor. Appl. Genet. 85: 568-576.

Petersen D.R., Reichard J., Kolaja K.L., and Hartley D.P., 1999. 4Hydroxynonenal and malondialdehyde heatic protein adducts in rats treated with carbon tetrachloride: immuno-chemical dection and lobular localization. Toxicol. Appl. Pharm. 161: 23-33.

Radic S., Radic-Stojkovic M., and Pevalek-Kozlina B., 2006. Influence of $\mathrm{NaCl}$ and mannitol on peroxidase activity and lipid peroxidation in Centaurea ragusina L. roots and shoots. J. Plant Physiol. 163: 12841292.

Ruiz J.M., Blasco B., Rivero R.M., and Romero L., 2005. Nicotinefree and salt-tolerant tobacco plants obtained by grafting to salinityresistant rootstocks of tomato. Physiol. Plant. 124: 465-475.

Sedmak J.J. and Grossberg S.E., 1977. A rapid, sensitive, and versatile assay for protein using Coomassie Brilliant Blue G250. Anal. Biochem. 79: 544-552.

Shimon-Kerner N., Mills D., and Merchuk J.C., 2000. Sugar utilization and invertase activity in hairy-root and cell-suspension cultures of Symphytum officinale. Plant Cell Tissue Organ Cult. 62: 89-94.

Van Breusegem F., Bailey-Serres J., and Mittler R., 2008. Unraveling the tapestry of networks involving reactive oxygen species in plants. Plant Physiol. 147: 978-984.

Verniquet F., Gaillard J., Neuberger M., and Douce R., 1991. Rapid inactivation of plant aconitase by hydrogen peroxide. Biochem. J. 276: 643-648.

Volokita M., 1991. The carboxy-terminal end of glycolate oxidase directs a foreign protein into tobacco leaf peroxisomes. Plant J. 1: 361-366.

Wang J., Zhang H., and Allen R.D., 1999. Overexpression of an Arabidopsis peroxisomal ascorbate peroxidase gene in tobacco increases protection against oxidative stress. Plant Cell Physiol. 40: $725-732$.

Zhu J.-K., 2001. Plant salt tolerance. Trends Plant Sci. 6: 66-71. 